\title{
As figuras da Lei em Platão e Kafka: do esclarecimento filosófico à parábola da impenetrabilidade
}

\section{The Law Figures in Plato and Kafka: From Philosophical enlightenment to the Parable of Impenetrability}

Edson José da Silvai (UFPE)

\begin{abstract}
Resumo:
A liberdade é um tema caro tanto à poesia quanto à filosofia, uma questão tangenciada por diversos autores, mesmo quando denunciam a opressão dos cárceres ou aconselham ao cumprimento da legislação. O objetivo deste trabalho é traçar um olhar comparativo entre o diálogo platônico "Críton"e o conto de Franz Kafka, "Na Colônia Penal", ao levar em consideração a representação da Lei como um tema comum às duas obras. Por meio da noção de interpretação figural apontada pelo filólogo alemão Erich Auerbach (1997), buscou-se o confronto entre as duas obras clássicas (CALVINO, 1993), no intuito de revelar o teor "iluminista" (ADORNO \& HORKHEIMER, 1975) da obra de Platão frente à construção literária do texto de Kafka, centrada no problema da impenetrabilidade do réu no cerne do sistema que o julga (ADORNO, 1998). Com efeito, percebe-se que a obra de Kafka, ao revelar os desdobramentos mais perversos da justiça, pode ser lida como um cumprimento figural da obra de Platão, uma provocação à harmonia de Sócrates em relação a Lei que ele mesmo, enquanto condenado, busca emular.
\end{abstract}

Palavras-chave: Kafka, Platão, Lei, Figura, Esclarecimento

\section{Resumen:}

La libertad es un tema importante tanto para la poesia como para la filosofia, un tema que muchos autores han tratado, incluso cuando denuncian la opresión de las cárceles o aconsejan el cumplimiento de la legislación. El objetivo de este artículo es dibujar una mirada comparativa entre el diálogo platónico "Crito" y el cuento de Franz Kafka "En la colonia penal", teniendo en cuenta la representación de la Ley como un tema común en las obras. A través de la noción de interpretación figurativa señalada por el filólogo alemán Erich Auerbach (1997), se buscó la confrontación entre las dos obras 
clásicas (CALVINO, 1993), con el fin de revelar el contenido "iluminista" (ADORNO y HORKHEIMER, 1975) del trabajo de Platón contra la construcción literaria del texto de Kafka, se centró en el problema de la impenetrabilidad del acusado en el corazón del sistema que lo juzga (ADORNO, 1998). De hecho, está claro que la obra de Kafka, al revelar las consecuencias más perversas de la justicia, puede leerse como una conclusión figurativa de la obra de Platón, una provocación a la armonía de Sócrates con la Ley que él mismo, como condenado, intenta emular.

Palabras claves: Kafka, Platón, Leys, Figura, Aclaración

\section{Introdução}

Este trabalho busca lançar um olhar comparativo entre o diálogo platônico Críton e o conto de Franz Kafka, Na Colônia Penal, levando em consideração a representação em abas as obras. Tanto Sócrates, em Platão, quanto o Oficial, no escritor tcheco, emulam o discurso da Lei, lastreando sua crença nos protocolos legais da tradição, seja nos deuses da polis grega, seja na figura do velho comandante, no caso da personagem kafkiana.

Porém, há distâncias abissais entre as obras, não somente do ponto de vista diacrônico, mas a representação mesma da Lei são-Ihes essencialmente distintas, o discurso "positivo" e límpido de Platão, herdeiro da tradição de representação transparente da realidade helênica (Auerbach ,1971) está diametralmente separado do discurso "negativo" e obscuro de Franz Kafka, entendido como um construtor de parábolas cerradas (Benjamin, 1987). Pelo sentido dado de interpretação figural pensando por Auerbach, pode-se dizer que a obra de Kafka estava prefigurada no diálogo de Platão e que o conto "Na Colônia Penal" é uma reescrita de Críton. Este será o ponto de partida deste trabalho.

Em um primeiro momento, busca-se refletir sobre o problema do Clássico, qualificativo comum às duas obras que serão comparadas, afinal, trata-se de dois dos maiores ícones da cultura ocidental, neste esteira, é de suma importância o pensamento de Ítalo Calvino acerca da validade do canônico enquanto processo, um vivo diálogo perene entre obras que se repelem e se completam para formar uma tradição.

Através do pensamento adorniano, o discurso filosófico grego será lido enquanto "esclarecimento", como depurador do pathos através da racionalidade, do logos. Terminada a reflexão acerca do fundador da Academia, buscar-se-á perceber a literatura, por meio da análise do conto "Na Colônia Penal", para ser lida enquanto discurso marginalizado pelo "iluminismo" filosófico, pelo seu caráter negativo, como também aponta Theodor Adorno. Por fim, será apresentada uma reflexão acerca do estatuto da filosofia e o da poesia e como 
a representação da Lei nas obras estudas por conta da tradição discursiva a qual pertence cada um dos textos.

Claro está que este trabalho possui seus limites, trata-se de abordar duas das maiores obras do cânone ocidental, de refletir dentro de um contexto contemporâneo onde a kafkiana realidade do mundo burocrático está associada à positividade cientifica surgida na cultura grega (seguindo a ideia de instrumentalização presente em Adorno); trata-se também de reconhecer as limitações de uma leitura traduzida das duas obras do corpus; porém, em um país que possui mais de seiscentos mil presos, uma reflexão acerca das obras que colocam em questão a relação entre o indivíduo e a Lei, pode ser bem-vinda para um debate sobre questões como a liberdade, ponto onde poesia e filosofia podem se tocar.

\section{Os clássicos pela leitura figural}

Se asseverarmos o pensamento de Ítalo Calvino (1993) acerca dos clássicos, não vamos entender o termo enquanto estilo demarcado temporalmente, como as obras escritas somente entre os Gregos ou Romanos, portadoras de uma suposta autoridade incontestável. Clássico, no sentido que um grande leitor e escritor como Calvino adota, é um texto sempre potencializado através das leituras. "Um clássico é um livro que nunca terminou de dizer aquilo que tinha para dizer" (p. 11). É um texto vivo e rico e, por esse mesmo motivo, não aceita códigos hermenêuticos cerrados, pois é "uma obra que provoca incessantemente uma nuvem de discursos críticos sobre si, mas continuamente as repele para longe" (p. 12). Também a mirada do grande escritor, leitor e crítico italiano leva mais longe, além de realçar o caráter múltiplo e irrequieto do clássico e cobrar da leitura destes uma postura para além dos escapismos, Calvino defende que a relação entre os clássicos é de suma importância à perenidade histórica dos textos: "Um clássico é um livro que vem antes dos outros clássicos; mas quem leu antes os outros e depois lê aquele, reconhece logo o seu lugar na genealogia" (p. 14).

É por meio deste pensamento vivificante sobre o clássico que este trabalho busca delinear esta leitura entre Platão em Kafka. Para tanto, este trabalho será urdido por uma reflexão comparativa sob a noção de interpretação figural, que, desde a Antiguidade, foi vista como um método de leituras de textos e construção da tradição literária do Ocidente.

A noção de leitura figural emerge no seio da Patrística e é recuperada pelo filólogo alemão Erich Auerbach (1997). Trata-se do método de cotejar os textos do Velho Testamento 
com os escritos da tradição cristã, no sentido de conectá-los em uma mesma tradição; ao apresentar o último enquanto cumprimento do primeiro.

O crítico alemão mostra como a interpretação figural da história está arraigada na cultura ocidental desde Tertuliano, para quem o termo figura é tratado por tendência ao realismo, fazendo uso do termo associado a Preenchimento, onde as figuras históricas são interpretadas espiritualmente (spirituliter interpretari), pois são a umbra ou imago de uma verdade histórica, como uma veritas, termo usado para designar o preenchimento. Esse procedimento vai perpassar toda a ideia de Figura na Idade Média e será comum entre os Pais da Igreja que a elegem como um viés interpretativo que se volta para uma realidade histórica concreta, diferente de outros tipos de interpretação, como a alegoria ou a interpretação simbólica. Auerbach (1997) nota que este tipo de interpretação marca um diálogo entre dois "lugares": "A interpretação figural estabelece uma conexão entre dois acontecimentos ou duas pessoas, em que o primeiro significa não apenas a si mesmo, mas também ao segundo, enquanto o segundo abrange ou preenche o primeiro" (p.46).

Neste sentido, o texto de Kafka, escrito mais de dois milênios, pode ser entendi como um preenchimento, uma "reescrita" do diálogo de Platão, desta forma, encontra-se um método para caminhar entre as fronteiras e planar sobre os abismos que liam ou separam as obras de Platão e Franz Kafka.

\section{Filosofia e esclarecimento, o caso de Platão}

Na República, a metáfora do Sol, urdida pelo teor didático da filosofia sobre o mito, aparece como uma "iluminação" que as trevas que assolam as paredes da doxa e do mito, que é desmascarado e racionalizado no bojo do projeto socrático-platônico. Também a aurora marca o fim do Banquete, de onde Sócrates sai sem ressacas ou embriaguez. Neste sentido, o discurso socrático, ancorado na tradição forjada por Parmênides, aparece como um dissipador das impressões enganosas do mundo sensível, busca marcar um ponto de inflexão na Paidéia grega fincada no saber homérico. Friedrich Nietzsche, grande crítico do legado platônico, identifica no discurso socrático o agente destrutor do pathos que a tragédia ática resguardava da autenticidade do mito:

Também Eurípides foi, em certo sentido, apenas máscara: a divindade, que falava por sua boca, não era Dionísio, tampouco Apolo, porém um demônio de recentíssimo nascimento, chamado Sócrates. Eis a nova contradição: o dionisíaco e o socrático, e por causa dela a obra de arte da tragédia grega foi abaixo. (NIETZSCHE, 1992, p. 79)

Eutomia, Recife, 24(1): 75-95, Set. 2019 
A noção de filosofia enquanto um discurso "iluminista", centrado no esclarecimento frente o discurso mitológico presumidamente obscuro, foi de suma importância para formatar a abordagem que esta reflexão pretende desenrolar sobre a obra de Platão, neste sentido, a obra de Theodor Adorno e Max Horkheimer (1985) apresenta uma mirada provocativa sobre o discurso socrático: "Com as Idéias de Platão, finalmente, também os deuses patriarcais do Olimpo foram capturados pelo logos filosófico." (p. 18).

Os estudiosos de Frankfurt, ao utilizarem o conceito de "lluminismo" para observar tanto a formação do pensamento grego quanto o movimento intelectual burguês do século XVIII não deixa de apontar o processo de desmistificação nos escritos de Platão, sendo assim "O equacionamento mitologizante das Ideias com os números nos últimos escritos de Platão exprime o anseio de toda desmitologização: o número tornou-se o cânon do esclarecimento. As mesmas equações dominam a justiça burguesa e a troca mercantil" (ADORNO; HORKHEIMER, 1985, p. 19).

Na leitura do texto de Kafka, ver-se-á que sua obra construída de metáforas sobre impenetrabilidade, de ambientes obscuros e decadentes, da tensão que emerge da angústia de quem é oprimido por uma força tão irresistível quanto obscura pode ser entendida como um preenchimento, uma resposta ao texto de Platão, se visto pela leitura figural.

Pela chave que Nietzsche utiliza para entender o discurso filosófico, com o Sócrates platônico, nasce a filosofia e morre a tragédia, sai de cena o homem dionisíaco e entra o homem teórico:

Se com efeito o artista, a cada desvelamento da verdade, permanece sempre preso, com olhares extáticos, tão-somente ao que agora, após a revelação, permanece velado, o homem teórico se compraz e se satisfaz com o véu desprendido e tem o seu mais alto alvo de prazer no processo de um desvelamento cada vez mais feliz, conseguido por força própria. (NIETZSCHE, 1992., p. 92-3)

Além da mirada que interpela Platão dentro da noção de "iluminista" filosófico, esta reflexão não entende Sócrates somente como encarnação da decadência do espírito ático, como pensava Nietzsche, mas também como um artífice da linguagem, percepção erigida desde Dioniso de Helicarnasso, crítico grego do século I a. C. responsável por uma mirada sobre o aspecto composicional das obras do helenismo (SANTOS, 2008).

Observar a obra de Platão como um artifício da linguagem, na construção das personagens e de seus discursos, isto é, sob o plano dramático e argumentativo, permite 
uma abordagem que esta leitura busca desnudar na relação entre o réu Sócrates e "Críton", como também na representação que é feita da Lei, construída por meio da metodologia da pergunta/resposta da forma elênctica.

Do ponto de vista do contexto de produção, o período em que Platão compõe suas obras é o tempo da explosão e da hegemonia de uma novo tipo de gênero, o "diálogo socrático", praticamente toda obra filosófica da Academia foi tocada pelo sokratikoi logoi; enquanto a velha forma de escrever aforismos (Heráclito) ou narrativas filosóficas (Parmênides) dos antigos pré-socráticos ficou estagnada na sua geração de origem. Os diálogos, duas décadas depois da morte de Sócrates, tornou-se praticamente onipotente enquanto forma de escrever filosofia. O próprio Aristóteles, primeiro grande teórico, crítico e historiador dos textos dramáticos, apresenta a dificuldade de enquadrar os textos de Platão, o que assinala, em certo sentido, a originalidade do gênero utilizado pelo seu mestre:

Todavia, a [arte] que imita apenas com palavras em prosa ou em verso, podendo misturar-se diferentes metros ou usar um único, chegou até hoje sem nome. Realmente não temos nenhum termo comum para designar os mimos de Sófron e de Xenarco e os diálogos socráticos, ou a imitação que alguém faça em trímetros, em versos elegíacos ou alguns outros metros similares. (ARISTÓTELES, Poét. $1.447 \mathrm{~b}$, grifo nosso).

Segundo o professor italiano Livio Rossetti (2006), estudioso da figura de Sócrates, durante os anos 395-385 a. C., os socráticos atingem o clímax da sua produção intelectual. Pelo gênero do diálogo, vive-se um contexto de uma espécie de "revolução de veludo", a hegemonia desse gênero representa também uma mudança nos modos de filosofar; Rossetti dá a dimensão do ponto de ruptura deste novo molde de escrever filosofia:

Durante a primeira metade do século quarto, o grupo de socráticos que esteve envolvido na invenção e utilização do assim chamado diálogo socrático, composto por algo como de doze a quinze pessoas, foi autor de mais de "duzentos" trabalhos, divididos em um número ainda maior de livros. Seus escritos têm a probabilidade de ter incluído não menos (ou mais) do que "trezentos" diálogos socráticos (incluindo um número de unidades dialógicas curtas ou muito curtas). (ROSSETTI, 2006, p. 2)

Vários são os autores que não voltaram mais ao velho modelo do tratado pré-socrático, é o caso de Cebes, Críton, Ésquines de Sfeto, Fédon, Glauco, Símon etc. Um traço muito importante na composição do gênero é uma intersecção entre a poesia e pensamento, Rossetti aponta esta relação entre o filósofo e o dramaturgo. "Com efeito, em poucos outros períodos da filosofia ocidental uma determinação de diluir, senão de totalmente dissolver a diferença entre filosofia e literatura, atingiu um nível comparável" (ROSSETTI, 2006, p 8). 
Como se vê, a mirada que define Platão como um poeta-filósofo e o insere tanto na tradição literária permite esta relação com obra de Kafka.

\section{2 "Críton" ou "Do dever": a Lei como esclarecimento}

Após este recorrido, é possível demarcar certos pontos que lastreiam a interpretação do diálogo "Críton": I) O contexto histórico e de produção da obra de Platão está encravada na explosão do diálogo socrático enquanto gênero hegemônico da época; II) O caráter aberto da obra de Platão, centrada no diálogo de iluminação das ideias e no não-dogmatismo e III) O discurso "iluminista" da filosofia, do logos que radicaliza o esclarecimento e valoriza a razão em detrimento do discurso patológico do mito, conforme o supracitado argumento nietzschiano.

A peça trata de um diálogo entre Sócrates e Críton, um poderoso aristocrata ateniense e um dos amigos mais influentes do filósofo. A obra é um dos quatro diálogos ${ }^{1}$ que abordam

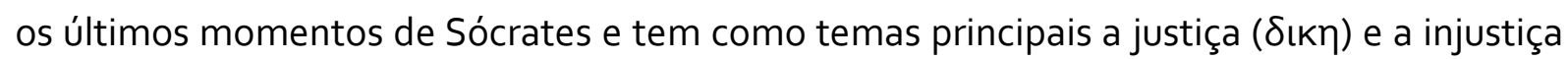
( $\alpha \delta$ IKı $\alpha)$. A peça se dá em um único espaço: a cela onde Sócrates dormia, esperando sua dose de cicuta; Críton tenta convencer seu amigo a fugir para outra cidade-estado, para evitar a pena capital; segundo ele, tudo já estaria acertado, desde o suborno dos sicofantas até a logística do fugitivo; porém, Sócrates, com sua ironia habitual e seus jogos argumentativos, chama atenção para a impossibilidade ética de fugir da cadeia, desobedecendo assim a Lei que verte dos deuses.

Para defender sua decisão de respeito à Lei, Sócrates chega a emular a voz desta última no seu próprio discurso de réu e assim vai para o cumprimento da pena capital. Do ponto de vista da organização da peça, trata-se do modelo da dialética socrática, assentada na metodologia do discurso elênctico; através de perguntas, Sócrates conduz seu amigo através de seu discurso pedagógico, maiêutico; neste sentido, "Críton" é um dos diálogos mais "característicos" da obra platônica, apesar da sua própria autoria seja contestada, o que não tira seu pertencimento do ciclo do "diálogo socrático", ademais em um período onde a autoria não possuía o mesmo estatuto personalista do autor moderno

O Sócrates de Platão encarna a dialética e também é um homem histórico, que vive na Grécia do século IV, quer dizer, sua presença está entre uma personagem que, ao mesmo tempo, aparece enquanto arauto de um pensamento dentro de uma problemática da ação,

\footnotetext{
${ }^{1}$ Ao lado da Apologia de Sócrates, Fédon e Eutífron
} 
essa dualidade é a característica central dessa personagem-pessoa: "La dualité du statut de Socrate, dans ces oeuvres qui se veulent à la fois philosophiques et biographiques : statut de philosophe et, simultanément, statut d'être humain et de citoyen intégré dans sa "polis» ${ }^{2}$. (INGLESSIS-MARGELLOS, 1994, p. 89). Em "Críton", a construção do Sócrates obedece menos a uma discrição histórica de um evento do que a construção de uma argumentação filosófica. Na "Apologia de Sócrates", por exemplo, outro diálogo acerca dos últimos momentos de Sócrates, há uma diferença enquanto o tom do réu, que ainda discute a sentença frente seus acusadores. Em Críton, já enquanto condenado, Sócrates defende a legalidade lastreada pelos deuses, neste sentido, insiste Iglessis-Margellos (1994, p. 106): Le Criton étant un texte essentiellement philosophique et non pas historique, la voix du dieu sort masquée de la bouche des Lois, mais c'est bien le dieu qui exige du philosophe de ne pas trahir ses príncipes 3 .

Sendo assim, a leitura de Críton precisa levar em consideração o construto teóricofilosófico que a lastreia muito mais que uma pretensa mimesis de um determinado acontecimento histórico, afinal, Platão é menos um histor que descreve um acontecimento, que um construtor de personagens dentro do microcosmo do seu pensamento filosófico. Com efeito, a obra de um Platão, homem histórico, a representação da Lei no Críton parece estar em consonância com o conservadorismo político da classe aristocrata a qual o fundador da Academia pertencia.

Como já fora dito, o diálogo em questão tem, como cenário, a cela onde Sócrates espera sua pena; os personagens são o condenado, Críton e dois velhos, esses últimos são mais "figurantes" que ativos na peça. O ponto inicial da trama ocorre quando Sócrates é despertado pelo seu rico amigo. Críton usou sua influência de homem poderoso para visitar seu mestre e se mostra admirado com a placidez de Sócrates: "Muchas veces, ya antes durante toda tu vida, te consideré feliz por tu carácter, pero mucho más en la presente desgracia, al ver qué fácil y apaciblemente la llevas" $4(\mathrm{PLATÃO}$, Criton, 43b).

Críton avisa que Sócrates será executado no dia seguinte, e o mestre conta-lhe e um

\footnotetext{
${ }^{2}$ A dualidade do status de Sócrates, nas obras que se mostram ao mesmo tempo filosóficas e biográficas: status de filósofo e, simultaneamente, status de ser humano e de cidadão integrado à sua "polis".

3 O Críton seria um texto essencialmente filosófico, não um texto histórico, a voz do deus deixa oculta a boca da Lei, mas é o próprio deus que exige que o filósofo não traia seus princípios.

${ }_{4}$ Muitas vezes, já antes durante toda tua vida, te considerei feliz por teu caráter, mas muito mais na presente desgraça, ao ver que passas fácil e aprazivelmente.
} 
sonho: "Me pareció que una mujer bella, de buen aspecto, que llevaba blancos vestidos se acercó a mí, me llamó y me dijo: "Sócrates, al tercer día llegarás a la fértil Ptía"5 (Críton, 44b). Sonho de sentido claro como os vestidos brancos, como claro tenta ser o discurso filosófico do sokratikoi logoi frente ao evento da morte. Críton, um dos amigos mais ricos de Sócrates, nega-se a aceitar a condenação que pesa sobre o mestre e ainda teme ser interpretado como um amigo negligente $(44 \mathrm{c}$ ). Sócrates refuta o argumento dentro da sua noção que separa a doxa, discurso do senso-comum, contra a episteme, discurso filosófico; sempre a valorizar este em detrimento daquele, ele nega o discurso do populacho, identificando-o como uma não verdade:

- ¡Ojalá, Critón, que los más fueran capaces de hacer los males mayores para que fueran también capaces de hacer los mayores bienes! Eso sería bueno. La realidad es que no son capaces ni de lo uno ni de lo otro; pues, no siendo tampoco capaces de hacer a alguien sensato ni insensato, hacen lo que la casualidad les oferece ${ }^{6}$ (PLATÃO, Críton, 44d)

Neste ponto temos a demonstração de um dos traços obscuros que a iluminação filosófica buscava atuar: os dogmas do senso comum. Certamente, é do senso comum que um homem lute contra a morte, mas Sócrates, com ironia e placidez (com decadência, dirá Nietzsche) não quer evitar seu destino, desta forma, ele se distingue de todas as personagens tragédia ática, pois o pathos que a tragédia ainda guardava - sendo ela uma ponte entre o logos da polis e o pathos dos tempos homéricos - não permitia esta iluminação e complacência do seu herói frente a seu destino, veja-se, pelo exemplo de Sófacles, onde o cego Tirésias é responsável por mostrar o turvo destino de Édipo e de Creonte, o sábio cego da Tragédia não pode revelar a mesma iluminação que o buscador da sabedoria, o filósofo.

Críton coloca seus haveres à disposição para uma possível fuga de Sócrates. Tudo poderia ser acertado, os amigos mais poderosos do filósofo, como Símias de Tebas e Cebes poderiam ajudar no suborno dos sicofantas venais. Porém, Sócrates nega-se a aceitar tal saída, afinal, o evento que marca todo discurso socrático, a saber, a morte de Sócrates, apenas torna mais sereno o pensamento do filósofo, que inquire seu amigo-aluno, esta prerrogativa é levada à radicalidade no momento da morte. Sendo assim, para observar o

\footnotetext{
${ }^{5}$ Apareceu-me uma bela mulher, de bom aspecto, que usava brancos vestidos e acercou-se a mim, chamoume e disse-me: "Sócrates, al terceiro dia chegarás à fértil Ptía

${ }^{6}$ Oxalá, Critão, fosse o povo capaz de praticar os maiores males, para ser capaz também das maiores benesses! Isso seria magnífico. Não o é, porém, nem destes nem daqueles. Incapaz de dar o siso, bem como de tirá-lo, se formam ao sabor das casualidades.
} 
problema através da racionalidade, Sócrates coloca em questão, através do método das elencas e de uma arquitetura argumentativa, se deve ou não aceitar fugir, uma vez que o texto versa sobre o "dever", quer dizer, da responsabilidade do homem dentro da polis, função que transbordaria a própria liberdade e vida do réu No Críton, Sócrates parte de uma assertiva de que não é possível negar a verdade ética do bem e da justiça, sempre por meio do reproche à doxa.

A representação da Lei ocorre no mesmo momento em que Sócrates, partindo de sua opinião que liga a justiça à bondade, estrutura seu argumento colocando em cena a própria Lei, enquanto uma voz que pergunta, sempre através da maiêutica: «Dime, Sócrates, ¿qué tienes intención de hacer? ¿No es cierto que, por medio de esta acción que intentas, tienes el propósito, en lo que de ti depende, de destruirnos a nosotras y a toda la ciudad?"7 (5ob). argumento passa pela justiça dessa convenção entre o cidadão e a polis, isto é, se Sócrates, até um dado momento, havia aceitado as Lei que organizavam a polis, por que deveria furtarse a respeitar este contrato por estar sendo condenado por ele? Continua a Lei a falar pela boca do esposo de Xantipa, para cobrar o seu contrato:

El que de vosotros se quede aquí viendo de qué modo celebramos los juicios y administramos la ciudad en los demás aspectos, afirmamos que éste, de hecho, ya está de acuerdo con nosotras en que va a hacer lo que nosotras ordenamos, y decimos que el que no obedezca es tres veces culpable, porque le hemos dado la vida, y no nos obedece, porque lo hemos criado y se ha comprometido a obedecemos, y no nos obedece ni procura persuadirnos si no hacemos bien alguna cosa. ${ }^{8}$ (PLATÃO, Críton, 51e)

A Lei é representada por Sócrates como portadora de uma voz de habilidosa argumentação e fala em termos jurídicos. Trata-se de uma das mais importantes peças de argumentação jurídica do mundo ocidental. A Lei inverte o argumento da fuga defendida por Críton, "provando-a" jurídica e filosoficamente inconsistente, por fim, o discurso de réu é depreciado pela sua própria condição de marginal tresdobrado da legalidade. Como Sócrates e Críton poderiam negar este contrato? O primeiro, exceto na guerra, apenas uma vez havia

\footnotetext{
7 Diga-me, Sócrates, o que tens a intenção de fazer? Não é certo que, por meio desta ação que intentas [a possível fuga] tens o propósito, que de ti depende, de nos destruir e toda cidade.

${ }^{8} \mathrm{O}$ que de vocês ficarem aqui, vendo de que modo celebramos os juízos e administramos a cidade nos demais aspectos, afirmamos que este, de fato, vai estar de acordo conosco [as Leis] e que vai fazer o que nós ordenamos, e dizemos, o que não obedeça será três vezes culpados, porque o temos dado vida, e não nos obedece, porque o criamos e se comprometeu a obedecer-nos, e não nos obedece nem procura persuadir-nos se não fazemos boa alguma coisa.
} 
saído dos limites de Atenas; o segundo, é um dos homens mais poderosos da cidade. A Lei continua desenhando seu discurso e, representada segundo a ironia socrática, mostrar-lhes o quão integrados são o réu e seu amigo.

Como pode-se observar, a personagem do diálogo platônico está em uma relação aberta com a Lei, chegando até a emular a voz desta. Esta representação deixa à mostra o caráter "iluminista" do discurso filosófico, conforme apontado por Adorno e Horkheimer (1985) e pode-se ainda apontar que este caráter torna-se mais patente na obra que, segundo o supracitado Iglessis-Margellos (1994), está menos interessada em um relato histórico sobre as últimas horas do preso do que expor a doutrina ética e filosófica do conservador aristocrata ateniense fundador da Academia.

O iluminismo filosófico que coincidiu com a derrocada política de Atenas é herdeiro daquele velho modo de representação da realidade próprio do mundo helênico, que fazia-se presente já no discurso homérico, um modo de "representar os fenômenos acabadamente, palpáveis e visíveis em todas as partes, claramente definidos em suas relações espaciais e temporais" (AUERBACH, 2002, p. 4). A representação da Lei em Platão busca este mesmo alvo iluminista para aclarar sua concepção do dever. A proteção da Cidade é colocada acima do indivíduo, através de um jogo retórico-jurídico, defesa que será ainda mais radical conforme Platão vai adentrando na sua fase mais madura. A Cidade e Lei são vistas, em Platão, iluminadas pelo seu moralismo geométrico do seu sol filosófico.

Porém, um outro texto, escrito há mais de dois mil anos depois do Críton de Platão e que também tem como tema a questão da Lei, pode trazer diversas provocações ao diálogo do fundador da Academia, trata-se do conto de Franz Kafka (1883 - 1924), "Na colônia penal" (In der Strafkolonie), escrita em 1914 e publicada cinco anos mais tarde. Além do tema, as duas obras podem apresentar outras contribuições para a relação (e abismo) entre filosofia e literatura, que se anuncia desde o livro X da República de Platão. Platão condena o artista por construir uma obra que seria a imitação do já enganoso mundo sensível, depois de denunciar o pathos danoso que a poesia lança sobre os guardiões da cidade (livros III e IV).

\section{A Literatura nas margens da Filosofia, o caso de Franz Kafka}

É evidente que há, entre os filósofos antigos, um desprezo pela figura do que, modernamente, pode ser chamado de artista. O reproche ao poeta é visto desde os fragmentos de Heráclito, mas é em Platão que essa tendência ocupa um papel preponderante, 
uma vez que o autor do República (livro X) lança uma leitura epistemológica do discurso artista, sendo ele cópia da cópia (mundo sensível) do mundo das Ideais. Com efeito, Platão aponta para o teor obscuro, do aspecto de sombra duplicada do trabalho do poeta. Essa visão de arte como um discurso que subverte a luminosidade do discurso filosófico é levada à sua radicalidade na obra de Franz Kafka.

É famosa a parábola do homem perante a Lei, que figura no Processo [Der Process, 1912]; um homem posta-se frente de uma porta que nunca se abre. Esta parábola não é somente o ponto nevrálgico do romance supracitado, como inocula seu tradutor Modesto Carone (2009, p. 82), mas é também uma parábola sobre a própria obra de Kafka, marcada pela composição de personagens que, como um Jó moderno, não conseguem chegar ao cerne da máquina que faz girar seu próprio mundo. É assim com o jovem Gregor Samsa, na novela Metamorfose [Die Verwandlung, 1915], transformado em inseto, torna-se marginal no seio familiar; questão que é também suscitada no processo de Josef $K$. ou no sistema burocrático a que está sujeito o agrimensor K., no Castelo. Pelo nome e marginalidade das personagens, fica evidente o cotejo com a vida do próprio escritor.

Em um célebre estudo, Günter Anders pensa acerca das particularidades da prosa kafkiana, e esboça diversos elementos, níveis e ângulos interpretativos acerca da obra do escritor de "Na Colônia penal". O crítico busca definir o realismo kafkiano como deformado por um estranhamento perante o cotidiano moderno, onde reina o escândalo da transformação do homem em coisas, e esta representação do cotidiano, deformado pela trivialidade de personagens grotesco e marginais, causa uma irrealidade e precisão, uma discrepância, eis de onde surge o choque ao ler Kafka, pois esta "discrepância gera, por sua vez, um efeito de choque; e esse efeito de choque produz, por sua vez, o sentimento da mais aguda realidade" (ANDERS, 2007, p. 24).

O homem kafkiano é um estranho, que precisa identificar-se, já que seu "eu" é uma espécie de não-ser, de não-pertencer. Sua épica consiste na tentativa desse ente despossuído de presença - como revela Anders ancorado em Heidegger -, encontrar um ser que lhe é negado, impossibilitando uma experiência autêntica. Ou, ainda segundo a dinâmica interpretação Anders, a obra de Kafka revela um estranhamento no seio da sociabilidade do Capital; se Marx, principal crítico deste sistema econômico, denuncia o estranhamento através do fetichismo da mercadoria, Kafka desmascara o mundo enquanto além, uma dimensão embargada pela mercantilização ou burocratização do homem. 
Como se vê, a crítica de Kafka ao sistema do capitalismo está para além do iluminismo filosófico tanto no seu florescimento no mundo helênico como também nos pensadores modernos. Anders, para realçar ainda mais a marginalidade particular de Kafka, o coloca frente a outros personagens sem mundo, desterrados, como D. Quixote e Robinson. Mas enquanto o personagem de Cervantes responde sem ser perguntado, o homem kafkiano sempre pergunta, mas nunca recebe uma resposta; ele está fechado em uma marginalidade profunda, muito mais radical que muitos textos da tradição filosófica e literária do mundo ocidental; afinal, Kafka escreve em uma era catastrófica do breve Século XX 9.

Theodor Adorno (1998) fala dessa antevisão kafkiana acerca do surgimento do Nacional Socialismo; na narrativa kafkiana, há uma atmosfera claustrofóbica, de inferno e campo de concentração, como no ambiente árido no conto "Na Colônia Penal". Em certo sentido, a crítica de Adorno, assim como a de Günter Anders também revela a marginalidade de Kafka; para o filósofo da Escola de Frankfurt, os heróis de Kafka são resíduos do sistema social, "nenhum herói de Kafka presta um serviço socialmente útil" (p. 252), são heróis supérfluos, antiquados que não servem à sociedade nem à sua Lei.

Para Adorno, Kafka é um parabolista da impenetrabilidade, seus personagens nunca estão onde deveriam estar, sempre faltam-lhe algo, "a fuga atravessa o homem até chegar ao desumano - esta é a trajetória épica de Kafka" (p. 247). A prosa de Kafka também causa uma certa impenetrabilidade perante seu leitor, em livros como a Metamorfose a relação contemplativa leitor/obra é implodida pelo choque do estranhamento e a opacidade da parábola kafkiana rouba a chave para uma interpretação estanque e autoritária da obra, para ler Kafka é preciso observar justamente os lances dessa opacidade, "fixar-se nos pontos cegos e nos detalhes incomensuráveis e intransparentes" (p. 243). Para Adorno, a autoridade de Kafka é a dos seus textos abertos às interpretações, particularidade essencial do texto kafkiano.

Veja-se que os dois críticos do autor tcheco apontam uma impenetrabilidade que acossa as personagens das narrativas deste e apontam a crítica profunda que a obra do escritor tcheco desencadeia contra a reificação do homem moderno. A leitura de outros críticos poderiam corroborar os estudos de Adorno e Anders, como a marginalidade Kafkiana atestada pela "literatura menor" pensada por Deleuze e Gattarri e sua potencialidade política;

\footnotetext{
9 Eric Hobsbawn (1995) aponta o "breve século XX" entre 1914 e 1991. O século dos extremos começa com uma era da catástrofe (até 1945) que assiste a duas Guerras Mundiais, Holocausto, Crise de 1929 etc.
} 
a negação da interpretação simplista e teológica também está presente em W. Benjamin, quando aponta a natureza das parábolas sem doutrina em Kafka, além de apontar para o ambiente decadente das personagens e do mundo obscuro do autor, uma vez que "toda obra de Kafka representa um código de gestos, cuja significação simbólica não é de modo algum evidente" ( BENJAMIN, 1987: 146).

\section{2 Na Colônia Penal e a Lei obscura}

O conto "Na Colônia Penal" foi escrito 1914 e publicada somente cinco anos depois, por Kurt Wolff, judeu de origem alemã que também publicava outros semitas além de Kafka, como Franz Werfel. A distância entre a escrita e publicação demonstra como o processo de publicação era problemático. A obra foi publicada no Brasil tardiamente, somente nos anos cinquenta, mas ainda em uma tradução do inglês; a tradução direto do original teria que esperar a década subsequente. (DE SOUSA, 2005, p. 232).

O conto tem um narrador heterodiegético, porém concentra-se no ponto de visto da personagem "o explorador", a trama se desenrola em um curto espaço de tempo e se passa nos trópicos, em um vale, ambiente árido e quente. Todas as personagens respondem por arquétipos: Oficial, Explorador, Condenado, Soldado, gerado pela construção da alegoria enquanto procedimento muito utilizado em Kafka, um crítico voraz da burocratização do homem moderno em seus papeis sociais. Neste ambiente árido da colônia francesa, encontra-se quatro personagens, o condenado "um homem de boca grande e aspecto estúpido, de cabelo e rosto descuidados" (KAFKA, 2011, p.31); o Oficial, que explica o funcionamento da máquina de condenação; o Soldado e o Explorador.

O conto começa quando tudo já parece estar pronto para que o condenado seja executado, o oficial faz questão de demonstrar a eficácia da sua máquina e da lei que sustenta a condenação, porém ele mostra-se descontente pelo constante avanço da degradação daquele sistema de legalidade e relembra com profundo saudosismo os tempos do velho comandante. Em um ato de devoção à Lei, ele mesmo torna-se condenado; a máquina, que não funciona perfeitamente conforme dizia o oficial, desfaz-se em pedaços; por fim, o explorador, depois de assistir a morte do oficial, chega na confeitaria, um local igualmente claustrofóbico "um espaço profundo, de teto baixo, cavernoso de paredes e altos enegrecidos pelo fumo" (KAFKA, 2001, p.32), lá ele visita o túmulo do velho comandante, assim termina a viagem "antropológica" do explorador na Colônia Penal. 
A obra lança mão de elementos essenciais da narrativa kafkiana, como a tensão, o ambiente claustrofóbico e o estranhamento frente ao sistema legal. O condenado, que não fala francês, não entende o que os homens da lei lhe dizem, encontra-se naquela mesma parábola do homem perante a Lei, presente n'O Processo.

O oficial e o soldado são aquelas figuras decadentes apontadas por Walter Benjamin; a descrição realista da máquina de condenação, com os detalhes das suas engrenagens e dinâmicas dá o tom absurdo do realismo kafkiano, além de oferecer uma profecia acerca das máquinas de matar dos Estados Totalitários que emergiram das trincheiras da Primeira Guerra.

A representação da máquina de condenação está dentro da tradição kafkiana de penetrar nas engrenagens dos sistemas punitivos. A máquina da condenação é um elemento da representação da Lei em Kafka, trata-se de um sistema arcaico, que o oficial faz questão de ostentar como uma invenção do antigo comandante. A máquina escreveria sobre o corpo do condenado pontos da mesma lei que este teria infligindo, porém, o próprio corpo do oficial comprova que o maquinário já se encontra inapto.

Embora o Oficial aponte os elementos que formam a máquina (Ancinho, Cama e Desenhador), como os advogados explicam o sistema burocrático da lei que condena Josek K., esse sistema não é posto de forma "iluminista", mas os diversos elementos do sistema da lei (ou da máquina da lei) aparecem como que dentro de um mundo decadente. Com efeito, o Condenado não tem acesso ao cerne que comanda a lei, o que aparece-lhe é apenas as capilaridades punitivas e "instransparentes" de um sistema que o tortura. De tão marginal que são, as personagens de Kafka, como o condenado da Colônia Penal, penam nas bordas, na periferia do sistema da legalidade.

O condenado do conto jamais poderia entender os mecanismos da máquina, pois não chega nem ao menos a falar a mesma língua do sistema prisional, o francês, kafkiana e ironicamente a língua do lluminismo filosófico. A discrição do sistema da máquina é um bom exemplo do inquietante realismo kafkiano, parece que estamos perante uma máquina do Himmler:

Há duas espécies de agulhas, dispostas de modo diverso. Cada agulha longa vai acompanhada por uma mais curta. A longa reduz-se a escrever, e a curta atira água, para lavar o sangue e manter legível a inscrição. A mistura de água e sangue corre depois por pequenos canaizinhos, e por fim desemboca neste canal principal, para derramar-se no buraco, através de um cano de desaguamento. (KAFKA, 2011, p. 39) 
O Oficial não só quer executar a lei, mas que defendê-la, como um bastião da antiga constituição do velho comandante. O seu aspecto segue a recorrente representação dos homens da lei kafkianos, que se vestem de forma antiquada, com "sua jaqueta de gala, ajustada, carregada de presilhas e de enfeites" (KAFKA, 2011, p. 3). Muito assemelha-se com os trajes dos oficias que abordam Josef $K$. no começo do Processo. O oficial é um homem tão dedicado à lei e acredita de tal forma no velho comandante e nos padrões da legalidade de antanho, que morreria pelo próprio ordenamento legal. Então, em mais um dos gestos kafkianos absurdos, deitar-se para ser executado pela máquina da morte. Como um cumprimento figural do Críton, esta é a maneira kafkiana do personagem emular a lei. Não há mais uma visão clara de Sócrates perante as leis da polis. De forma irônica e cortante, o Comandante descobre que sua tão admirável máquina não passa de uma quinquilharia com os dias contados, assim como todo o decadente sistema penal. Sua devoção pelo velho comandante.

O ponto de vista da narrativa concentra-se sobre a personagem do explorador, ele é um típico personagem da épica kafkiana que chega em lugar desconhecido, como o agrimensor K. ao pé do Castelo; ele chega como uma espécie de observador perturbado com aquele ambiente cerrado onde "o sol caía com demasiada força nesse vale sem sombras, mal podia alguém concentrar os pensamentos" (p. 40). Ele está dentro daqueles expressionistas e turvos ambientes kafkianos. Porém, há um diferencial importante desse personagem da "chegada", deferentemente dos personagens que estão despossuídos do poder, o explorador do conto dispõe de um lugar privilegiado da hierarquia. Na verdade, ele é um visitante técnico, que está ali para explorar os processos da Colônia penal como quem vem da Metrópole, ele tem esperanças de modernizar os processos penais:

fundava certas esperanças no novo comandante, que evidentemente projetava introduzir, embora pouco a pouco, um novo sistema de processos; processos que a estreita mentalidade deste oficial não podia compreender. (KAFKA, 2011, p.48).

O Explorador é um agente da lei, mas o próprio fato de ficar estarrecido com aquela conjuntara tão anacrônica de punir demonstra que ainda não está ciente de todo o sistema penal que ele mesmo ajuda a executar; é claro que ele está em um ponto na hierarquia mais elevado que o oficial, mas mesmo assim, seu estranhamento mostra o quanto a complexidade da lei transborda sua visão. O lugar do soldado dentro da hierarquia é o grau 
mais baixo; ele não fala e age conforme suas atribuições de trabalho, amarra o condenado, o faz levantar, tira suas roupas, limpa o local de execução, serve a última refeição etc.

O soldado, assim como o condenado, não entende a língua francesa, o abismo linguístico entre os superiores (Oficial e Explorador) e ele, torna a sua condição ainda mais marginal. Ele respeita a rígida hierarquia da Colônia Penal e sua posição é tão marginal que sua condição se confunde com a do condenado. Veja-se a sua condição de subalterno, dentro daquele teatro dos gestos kafkianos: "Tinha enrolado a cadeia do condenado em torno das munhecas; apoiado com uma mão no fuzil, cabisbaixo, não se preocupava por nada do que acontecia". De tão passivo, o soldado chega a dormir e por isso é acossado pelo oficial, assim ele comete o mesmo erro pelo qual fora condenado. No final do conto, ele chega a comer ao lado do condenado e ainda tenta sair da Colônia, mas o explorador não o permite, apontando seu mastro ameaçadoramente contra aqueles, ele deixa claro quem é o mais alto e mais baixo da hierarquia da lei. O condenado é um despossuído, passou de soldado a condenado; não entende a língua em que o condenam, sua situação é "canina", assim como a condição a qual Josef K. se vê no ponto da sua morte, ele encontra-se:

Tão caninamente submisso, que ao que parece teriam podido permitir-lhe correr em liberdade pelos campos circundantes, para chamá-lo com um simples assovio quando chegasse o momento da execução. (KAFKA, 2011, p.31)

A representação deste Condenado torna ainda mais radical a condição de marginalidade dos despossuídos do poder da lei; ele está muito mais alijado do cerne da legalidade que o Josef K., que ao menos ainda fala a mesma língua daqueles que o processam. Sua marginalidade só não parece maior que aquela de Gregor Samsa, onde a condição de marginal apresenta-se na própria deformação do corpo do personagem e o coloca em condição radicalmente distinta do corpo familiar.

Mas o condenado da Colônia tem um final não letal, diferentemente das várias personagens marginais do autor, no entanto não há otimismo para Kafka, pois não há esperança para nós, homens modernos constrangidos pelas poderosas máquinas de punir, o condenado continua alijado do cerne da lei, esta é sua condição social. Desse modo, o conto apresenta um cenário desolador de diversas relações de poder que se desenrolaram no seio da modernidade e de toda a tradição ocidental de criar leis, inclusive nos seus tentáculos coloniais, como mostra o conto de Kafka. 


\section{Platão e Kafka: Filosofia antiga e literatura moderna}

Buscou-se demonstrar nestes comentários acerca do conto kafkiano como a representação do condenado, da maquinaria da legalidade, a hierarquia burocrática e a marginalidade do indivíduo perante a lei são marcas recorrentes na prosa de Franz Kafka. Claro está que há uma distância entre a Lei e o indivíduo dentro da prosa kafkiana, o que a difere radicalmente daquele iluminismo discursivo e filosófico da representação da lei no Críton de Platão. Jamais um condenado de Kafka emularia a lei, como um Sócrates antes de tomar cicuta, não há em Kafka um esclarecimento, o que existe é uma épica da negatividade, Kafka não dá voz a Lei, como Sócrates, mas faz ecoar as vozes dos marginalizados ao redor do poder centrífugo desta última.

Como já fora dito, embora tenha sido um grande compositor de Diálogos, Platão sustenta uma atitude de reprovação para com o artista; sua visão sobre o poeta épico ou trágico está balizada pelo moralismo conservador de uma polis ideal. Na "República" (Livro IV) o filósofo fala dos sentimentos perniciosos que os poetas épicos e dramáticos liberam, pathos prejudicial à formação dos guardiões da Cidade, somente através de um controle estatal a poesia poderia ter espaço na Politeia; ainda na mesma obra (Livro X), o fundador da Academia taxa como falsa a imitação do poeta, que imita o já enganoso mundo das aparências e está em dois graus alijada do mundo real das Formas.

Observar a poesia como um Outro, como marginal, desvio ao controle apolíneo (em termos nietzschiano) do iluminismo filosófico é um primeiro ponto para lançar um olhar sobre a relação que aqui buscou-se construir entre a diálogo de Platão e o conto de Franz Kafka. Certamente este iluminismo é uma característica central da cultura clássica e há nele uma linha de depuração do mito na Grécia que vai de Homero a Aristóteles, quer dizer, do final da idade arcaica até a degradação da polis grega.

Na poesia épica homérica, os deuses e homens conviviam numa relação de planos superior (divino) e humano (guerreiro), havia uma distância instransponível, porém, a relação que ocorria entre eles era de um cosmo iluminado, os deuses não abandonam os homens. $\mathrm{Na}$ poesia lírica as vozes individuais de poetas como Arquíloco ou Safo era possível somente no surgimento e da multiplicação da polis, os poetas líricos também problematizam as questões humanos mais além dos deuses. Já o poeta trágico o mito torna-se uma representação teatral, sua realidade mítica está dentro dos limites da realidade cênica, o pathos mítico das recriações trágica já se encontra em declínio no surgimento do discurso socrático, Eurípedes, 
amigo de Sócrates, através do drama demasiado humano de uma Medeia, já expulsava o mito das motivações e conduções dos atos humanos. Os pré-socráticos também haviam destituído o antigo lugar do mito para explicar o mundo físico. Platão transformou o mito em sistema de conceitos e Aristóteles, filósofo do Império, radicalizou o método filosófico em um mundo imperial especializado, ele depurou os elementos do mundo social através da analogia cientifica, assim, o iluminismo filosófico chegava no seu apogeu e a poesia e o mito, irmanadas pelo pathos que emanam, são colocados em posição subalterna pelo vigor apolíneo da filosofia.

Já a época de Kafka, primeira metade do século XX, é marcada pela derrocada da crença do iluminismo científico, do progresso, do positivismo que reinou por todo século XIX e que levaria a Europa a uma crise gravíssima, jamais a capacidade de matar foi tão desenvolvida, através da técnica bélica e suas diversas máquinas de destruição. Kafka presenciou os desdobramentos perversos da I Guerra e seus milhões de corpos entrincheirados e perfurados pelas metralhadoras. A crise humanitária da I Guerra é o fim do projeto Europeu moderno e capitalista que teria surgido no final do Medievo; a Colonização, o liberalismo, o lluminismo, o Positivismo... são movimentos que adensam, desde 1492, o processo de iluminismo filosófico que o Renascimento retomou dos Gregos para reprovar a Idade Média.

Trata-se do projeto da Modernidade, que mostra-se falho e repleto de contradições que no começo do século $X X$ desnuda-se como um mundo de reificação do homem, de instrumentalização do humano, o mundo onde o homem perdeu-se de si mesmo, apesar do iluminismo, da brancura, ele torna-se cego, como no romance de José Saramago, descendente confesso de Franz Kafka. Como se vê, a obra de Kafka cobra, como um marginal poeta, o obscuro das sombras que a luminosidade filosófica quer lançar sobre os homens. Kafka compõe uma população de personagens marginais, totalmente destituídos do mundo luminoso do cosmos, isto é que o faz moderno, diferença irredutível frente o discurso do iluminismo filosófico do autor de Críton. A poesia, ou a Literatura, como modernamente fora denominada essa antiga tradição, possui uma obscuridade irredutível ao discurso "colonizador" e iluminista da filosofia.

A diferença do discurso "iluminista" de Platão e do discurso "obscuro" de Kafka naturalmente possui seus desdobramentos na representação da Lei e de seus acusados das suas obras. A leitura de E. Auerbach (1971) opõe a narrativa homérica (descrição modeladora, iluminação uniforme, primeiro plano, univocidade) e a narrativa do Velho Testamento (realce 
e escurecimento, falta de conexão, multivocidade interpretativa) como duas fontes para a representação da realidade na literatura ocidental, pode-se dizer que o discurso kafkiano está inserido dentro da tradição bíblica, com sua construção de épicas de Jó's modernos, esta raiz histórica do judeu F. Kafka ajuda a entender aquela particularidade do obscuro no escritor tcheco.

No que concerne aos condenados, as obras se distanciam muito. Em Platão, estamos falando de um cidadão grego condenado pela Lei de Atenas por impiedade e por corrupção dos jovens da cidade; 70 anos, casado, pai de dois filhos, já lutou e se feriu na guerra, sua história se confunde com a biografia e o ideal ético urdido por Xenofonte. Já em Kafka, há um condenado do mundo moderno, despossuído de poder, reduzido a uma condição "canina", que nem ao menos sabe falar a língua do Estado que o condena.

Onde Platão diz poder ao filósofo, Kafka fala do despossuído frente a máquina do poder. Kafka não era um aristocrata como um Platão, não pertencia a polis, se estivesse na Grécia seria um bárbaro, sua dicção de tcheco não seria tolerada. Platão era ateniense, cidadão; Kafka era um judeu periférico, num lugar periférico da Europa. Kafka era estranho e fazia da estranheza seu grande trunfo. O condenado da Colônia Penal não tem acesso à palavra, ao poder. Se a palavra é o que nos faz humano, no dizer de Aristóteles, a narrativa de Kafka é sobre a desumanidade, do homem que se transforma em coisa, na dialética do não-ser. De fato, Kafka é o marginal que a polis iluminada de Platão insistia em construir através dos blocos do seu mundo das Formas. Ironicamente, como um espelho marginal, a obra de Kafka é um cumprimento moderno da figura da Lei pintada também ironicamente pelo iconoclasta Platão.

\section{Referências}

ADORNO, Theodor W. "Anotações sobre Kafka". In: Prismas: crítica cultural e sociedade, São Paulo: Editora Ática 1998. p. 239-270.

ADORNO, T.; HORKHEIMER, M. Dialética do esclarecimento. Tradução de Guido de Almeida. Rio de Janeiro: Jorge Zahar, 1985.

ARISTÓTELES. A poética clássica. Cultrix/EDUSP, 1981.

AUERBACH, Erich. Mimesis: a representação da realidade na literatura ocidental. São Paulo: Editora Perspectiva, 1971.

Erich. Figura. Trad. Modesto Carone. São Paulo, Ed. Ática, 1997.

ANDERS, Günther. Kafka: pró e contra, os autos do processo. Editora Cosac Naify, 2007.

BENJAMIN, Walter. "Franz Kafka: A propósito do décimo aniversário de sua morte" In: Magia e técnica, arte e política: ensaios sobre literatura e história da cultura Tradução: 
Sérgio Paulo Rouanet. São Paulo: Brasiliense, 1987.

CARONE, Modesto. Lição de Kafka - São Paulo: Companhia das Letras, 2009.

CALVINO, I. Por que ler os clássicos? Tradução: Nilson Moulin - São Paulo: Companhia das Letras, 1993.

DE SOUSA, Celeste HM Ribeiro, Eduardo Manoel de Brito \& Maria Célia Ribeiro Santos. "A recepção da obra de Franz Kafka no Brasil." Pandaemonium Germanicum 9 (2005): 227253.

HOBSBAWM, Eric. Era dos extremos: o breve século XX. São Paulo: Companhia das Letras, v. 2, 1995.

INGLESSIS-MARGELLOS, Cécile. "Socrate et son doublé" In: Revue des Études Grecques, tome 107, fascicule 509-510, Janvier-juin 1994. pp. 85-106.

KAFKA, Franz. Um artista da fome seguido de "Na colônia penal" \& outras histórias. Porto Alegre: L\&PM, 2011.

NIETZSCHE, Friedrich. O nascimento da tragédia ou Helenismo pessimismo. Tradução, notas e posfácio J. Guinsburg. São Pauto, Companhia das Letras, 1992.

PLATÃO. Diálogos. Traducción de J. Calonge Ruiz, E. Lledó Iñigo e C. García Gual. Madrid: Gredos, 1997.

ROSSETTI, Livio. "O diálogo socrático 'aberto' e sua temporada mágica". Hypnos. Revista do Centro de Estudos da Antiguidade. n. 16, 2006.

SANTOS, José Trindade. Para ler Platão I- A ontoepistemologia dos diálogos socráticos. São Paulo: Edições Loyola, 2008.

${ }^{i}$ Licenciado em Letras [Português/Espanhol], pela Universidade Federal Rural de Pernambuco. Mestre em Estudos Literários pela Universidade Federal de Alagoas. Doutorando em Teoria da Literatura pela Universidade Federal de Pernambuco. 